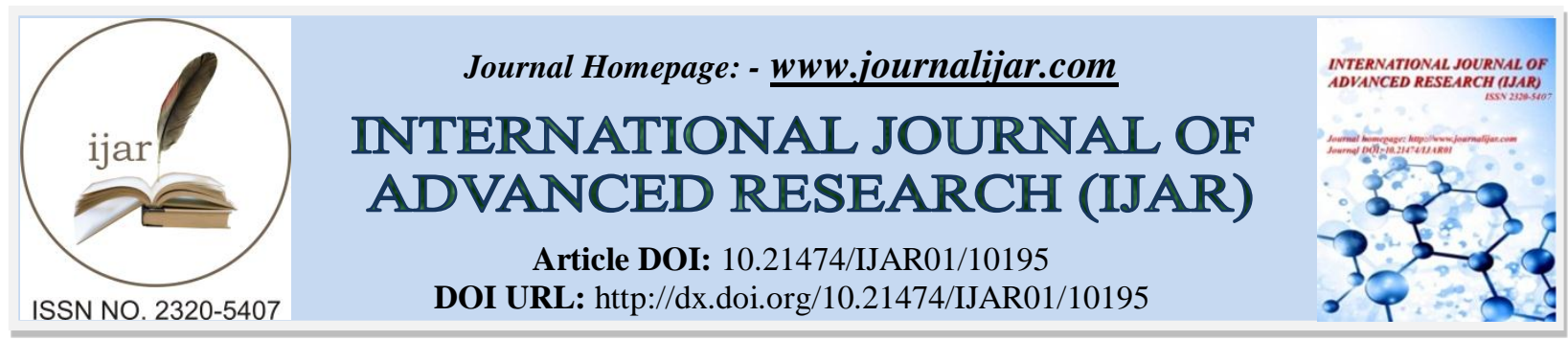

RESEARCH ARTICLE

\title{
MODELING OF URBAN WATER SUPPLY AND WATER LOSS IN DISTRIBUTION SYSTEM OF ADWA TOWN USING WATER GEMS V8I SOFTWARE
}

\begin{abstract}
Tsegay Brhane Beyene and Dr. Sisay Demeku
Department of water supply and sanitary engineering Addis Ababa science and technology universityAddis Ababa, Ethiopia.
\end{abstract}

\section{Manuscript Info}

Manuscript History

Received: 10 October 2019

Final Accepted: 12 November 2019

Published: December 2019

Key words:-

Water GEMS, Water Distribution System, Model Calibration

\begin{abstract}
There are oversized undersized pipes high pressure in the existing system caused by customers at too low demand have been identified and a solution is established using pressure reducing valve. The result showed that the water supply scope was very low which covers only $56.3 \%$, besides water demand and supply of Adwa town were not balanced. The residents of a town used daily water 13.76 litter for different domestic activities with the billed water amount is $69.9 \%$ of production and around $30.10 \%$ water is considered to be non-revenue (NRW) and the apparent losses and real losses of the town respectively. The other observed problem in Adwa town is recurrent pipe leakage the water distribution network during which the town water utilities do not have an instantaneous rejoinder for maintenance. Therefore, by considering the large water losses of the Adwa town water distribution system, a plan for the rehabilitation and modernization of UWDS must be established, starting with the GI pipes where the largest water losses are recorded.
\end{abstract}

Copy Right, IJAR, 2019,. All rights reserved.

\section{Introduction:-}

The water demand of the Adwa town is estimated by using; the data obtained from the socio-economic study, the projected population, livestock sizes, the various modes of services and there are respective per capita water consumptions. Hence, the estimated water demand accounts for the livestock water demand in addition to the domestic water demand of Adwa town. The public and the industrial water demands have also been estimated as the percent of domestic demand. During the survey, the sample households were also distributed for each kebele with different water supply converge, service level and new residential areas. The distribution was done using the land use type of the town, the kebele and the municipality official of the town (Addis et al., 2014). One of the common problems in the town water supply system was related to the water distribution system due to the topographical location of the town. Thereby, there was an inadequate quantity of water supplies and low coverage in the town. Therefore, this research work was prepared to model Adwa town water distribution network using waterGEMSV8i in hydraulic performance, water loss and leakage management

\section{General objective}

The general objective of the research is to model urban water supply and water loss in the distribution system of Adwa town using hydraulic simulation.

\section{Corresponding Author:-Tsegay brhane beyene}

Address:-Department of water supply and sanitary engineering Addis Ababa science and technology universityAddis Ababa, Ethiopia. 
Specific objectives of the study

1. to model the existing hydraulic characteristics of Adwa water supply distribution system outcomes using water GEMS V8i

2. to evaluate and compare the water losses in the selected sample area

\section{Research Methodology:-}

Description of the study area:

The study was conducted at Adwa town which is arranged within the central zone of the Tigray region, Ethiopia having a total range of ha. geologically, it is found at Scope: 110 38' 00"N Longitude: 370 56' 00" E. by the 2007 population and housing census of Ethiopia projection, the whole population of the town was assessed to be 60,748 people groups. The town is $1006 \mathrm{~km}$ from the North of Addis Ababa and $224 \mathrm{~km}$ away from the capital of Tigray, Mekelle. The most extreme rise of the town is 1,975 meters over the ocean level.
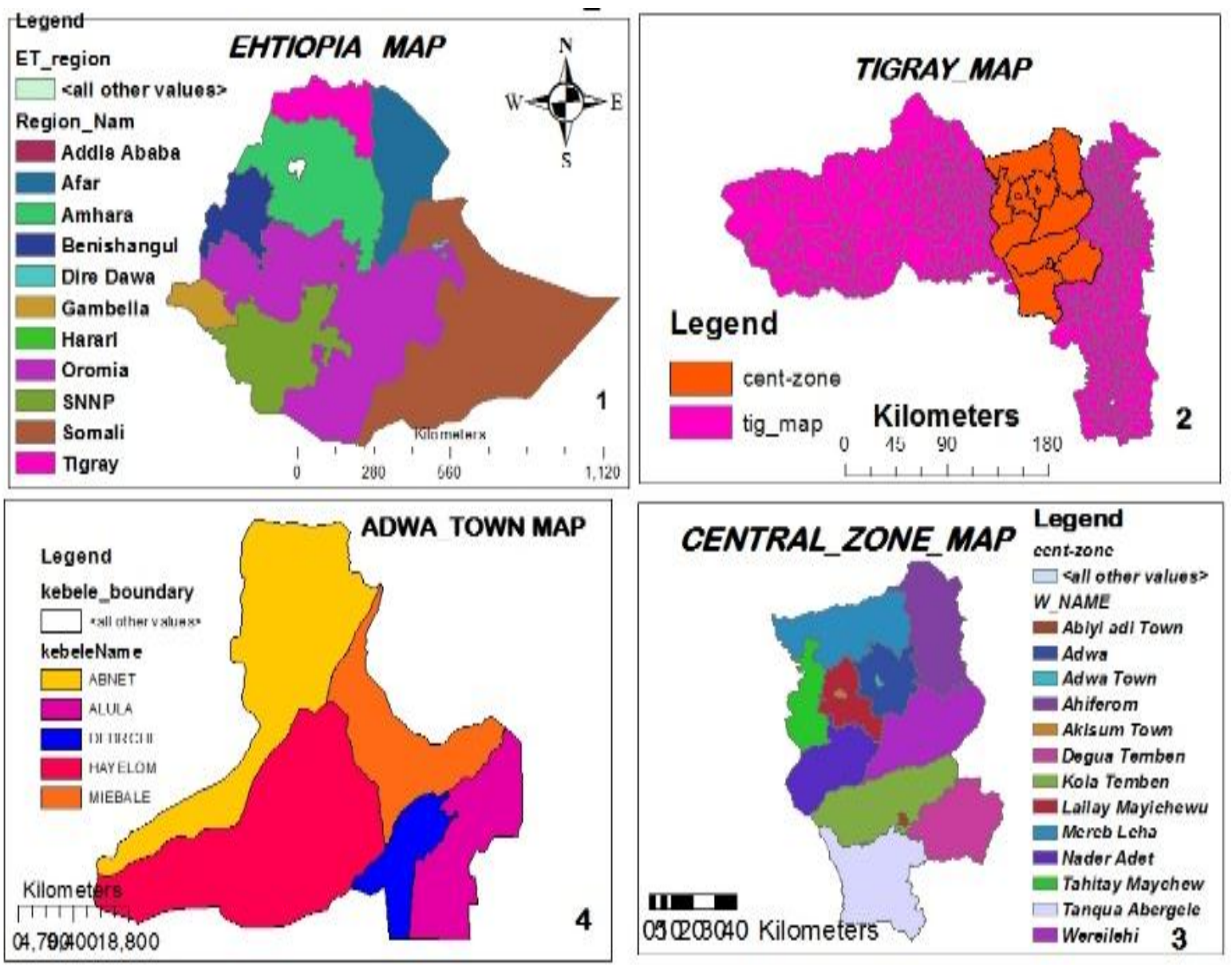

Figure 0.1:- Location Of Adwa Town.

\section{Materials and Tools:-}

This research was conducted on the modeling of existing urban water supply and water loss in the distribution system of Adwa town. To achieve the goal of the research the materials that were used are, Pressure gauge to measure the pressure at the nodes and pump outlet, water meter, to measure the flow of the pipe and handheld GPS to check the coordinates points, Acoustic /sound detector to receiver or transmitter antenna locate the pipe. software tools that have been used are, computer Mendeley, Google earth pro, ArcGIS version10.4.1, water GEMSV8i, AutoCAD2016. Microsoft excels. 


\section{Data Collection}

Afield visit the town of Adwa is conducted on December 8, 2018, with recognizable descriptive of clear and geographic information vital to coordinates water administration arrange and collect the information is included to the locale water organize database and GIS disobedient with the remaining data required and organizing for its collection. To determine the total water loss and trend of the loss, monthly water production and monthly water consumption records of all kebeles' private, public, institutions, commercial and industrial customers record of all sources for one year from April 2018 to March 2019.

\section{Population distribution by mode of service}

According to the CSA, the 2007census mode of services described above expresses the overall water supply coverage of Adwa town was indicated by $75.6 \%$ of this only $3.1 \%$ population were house tab connection users. The greater number of the populations was served their water need from the shared yard tab are covered $28.1 \%$ and $3.1 \%$ respectively. The public serves were covered by about $13.2 \%$ the remain the Neighborhood tap user will shift either to house or yard tap user and the traditional source users' shifts to Public tap users. This is because; as the living standard of the society improves their mode of service will also change accordingly. Based on CSA data 2007 its population of Adwa town was 51,294. Currently, the Adwa town of overall domestic water supply coverage was indicated $100 \%$ from this only about $13 \%$ of the total population is served by house connection $42 \%$-yard connection $35 \%$-yard connection shares and $10 \%$ use public services.

\section{Data Analysis:}

Per capita water consumption of Adwa town

In Adwa town the growth of socioeconomic activity in both governmental and private sectors there was high water demand in the town Hence, the per capita water consumption of the town was calculated using the annual water consumption recorded data and projected total population figure during (2019). Therefore, the average water demand of the town was calculated by multiplying the per capita demand with the estimated number of populations as follows.

per capital consumption $\left(\frac{\mathrm{L}}{\mathrm{c}} / \mathrm{d}\right)=\frac{\text { annual consumption } \mathrm{m} 3 \times 10001 \frac{\mathrm{l}}{\mathrm{m} 3}}{\text { total population } \times 365}$

\section{Assigning base water demand in each supply node}

To estimate the existing water demand of each node in the distribution network, it was necessary following the steps below; Once the average daily water demand of the system was determined, to calculate base water demand for the particular supply node the following equation was used (Zewdu, 2014)

\section{Base demand for supply node $=\frac{\text { population served by the node }}{\text { total population }} *$ ADD-------------(0-2)}

Finally, assigning manually the base water demand into the node. In the same excel sheet, all the node was those assigned base water demand the above equation the domestic water demand of Adwa town is $44.15 \mathrm{l} / \mathrm{sec}$ based on estimated base demand design 2019. APPENDIX - A table shows the sample calculation of domestic demand for assigning base flow water demands to each node. The industrial, commercial, institutional and public consumption of water was $16.73 \mathrm{l} / \mathrm{sec}$. to assigning the industrial, commercial, institutional and, public demand to each node was calculated using the flowing formula given below.

institutional water demand $=\frac{\text { Number of institution served by the node }}{\text { Total number of customers in the institution }} *$ consumed water demand------- $(0-3)$

Identification of number a of houses around each supply node

The urban geodatabase of the town-based ArcGIS format was obtained from the municipality of Adwa town. In ArcGIS, this, topographic map was displayed and the town distribution network map which was drawn in Water GEMS was exported into the ArcGIS shapefile and overlapped it in the topographic map of the town. Therefore, the number of houses in each census block was physically counted and assigned to the nearest supply node. An excel sheet was created for demand allocation. The first column counted all the 358 demand nodes. The second column showed the number of houses assigned to those nodes. the estimated population in 2019 is 70742 the total number of the residential house was identified in 17254 giving an average count of 4.1 people per house.

average people per house $=\frac{\text { Total current population }}{\text { Total number of the house }}$ $(0-4)$

Determination number of peoples in per single-family residence each supply node 
to calculate the population served to each node was the physical counted the number of a house near to the node multiplying the average number of people in each house of the

number of people for supply node number of houses assigned by that node $\times$ average number of people in each hous $(0-5)$

\section{Diurnal curve of water demand analysis for Adwa town:}

A diurnal curve is a type of pattern that describes changes in demand for a daily cycle. The variation in water consumption over a 24-hours was adopted which had been considered. The diurnal curve of Adwa town was developed using measuring primary data from supplying discharge in the outlet of the service reservoir. The flow data were measured in a day in 2 hours gap for seven successive days. For example, the peaking factor applied to average-day demands to obtain peak hourly demand can be calculated by using Equation.

$$
\text { Pf }=\frac{\text { peak hourly demand }}{\text { average day demand }}
$$

\section{Methods of the leak location:}

The methods of leak location relied on the detecting a noise, then tracing it at the ground level to find the point of the maximum noise, which was assumed to be directly above the position of the leak. the equipment used include listening sticks and stethoscopes, but these were difficult to use if the noise was faint or too loud to be accurately located. A correlator operates by comparing the noise detected at two different points in the pipeline. Noise travels from the leak in both directions along the pipeline at a constant velocity, so that if the leak is equidistant between two sensors then these sensors will detect the noise at the same time.

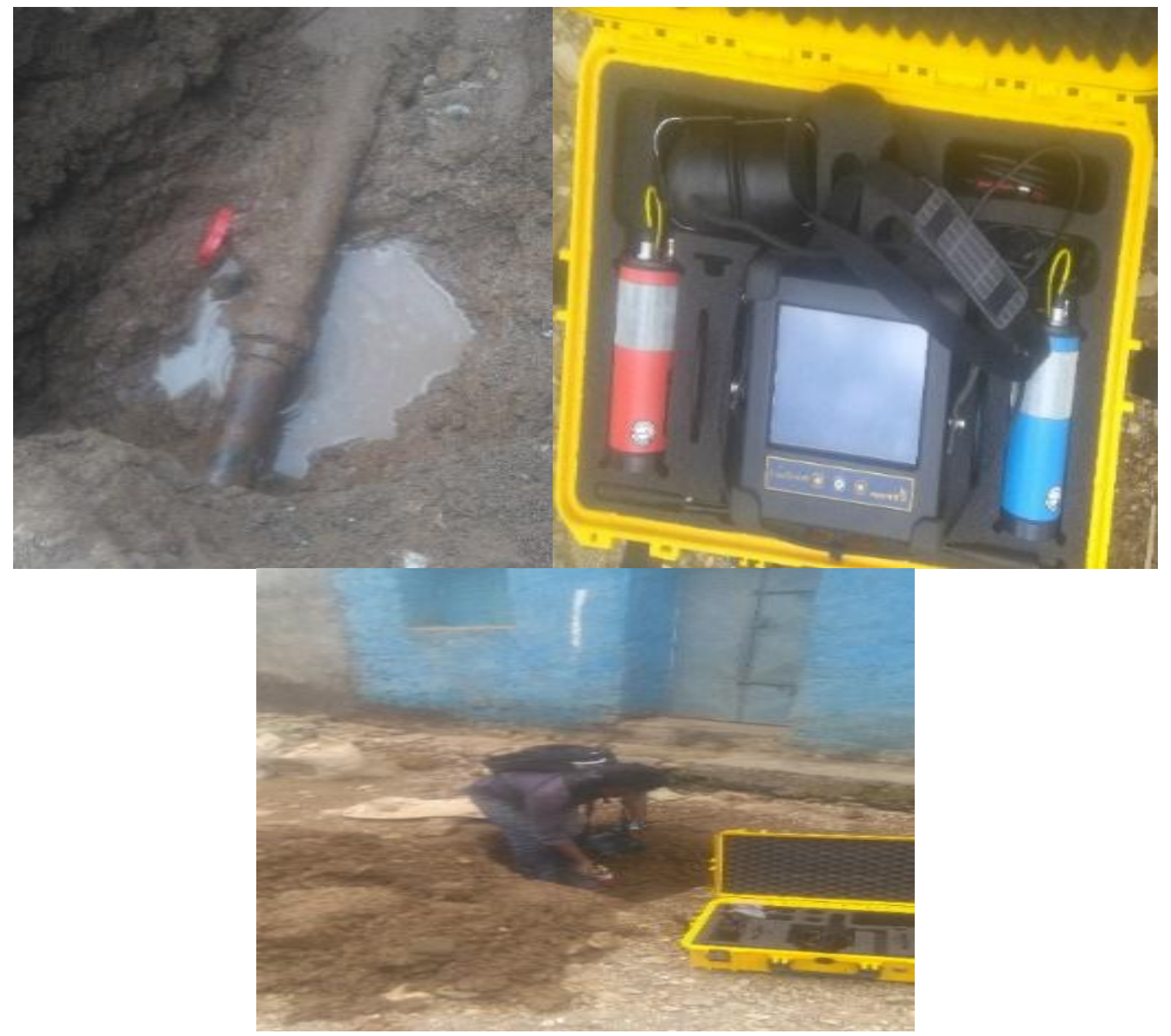

Figure 0.2:- Field measurement of leakage around Medihanialem Church. 


\section{Results And Discussion:- \\ General:}

This chapter presents the results of the analysis with quantitative statistical techniques, indicated and presented in tables, figures, graphs, and charts. Answers to research questions and objectives are sought through a descriptive analysis of modeling the water supply distribution system with water loss analysis. The magnitude of domestic water demand and distribution in Adwa town is discussed, and the key factors that influence the rate of water demand, and the current water loss management strategies concerning water consumption, accessibility, and water tariff are explained. The analysis was done based on study ideas and research enquiries. This chapter further provides a discussion on the study variables and their implications on domestic water demand, distribution, and management. The interpreted data analysis results become the findings of the research study.

\section{Water supply coverage analysis:}

According to Adwa town water supply service office report the water supply coverage of the town has been evaluated based on the average per capita consumption. The average per capita consumption has been derived from the yearly Consumption that was collected from someone domestic water meters. Statistical investigation remained used to evaluate the supply coverage for the total town and supply coverage map has been established using ArcGIS. There are a total number of 12356 customers including residential, commercial, institutional, industrial.

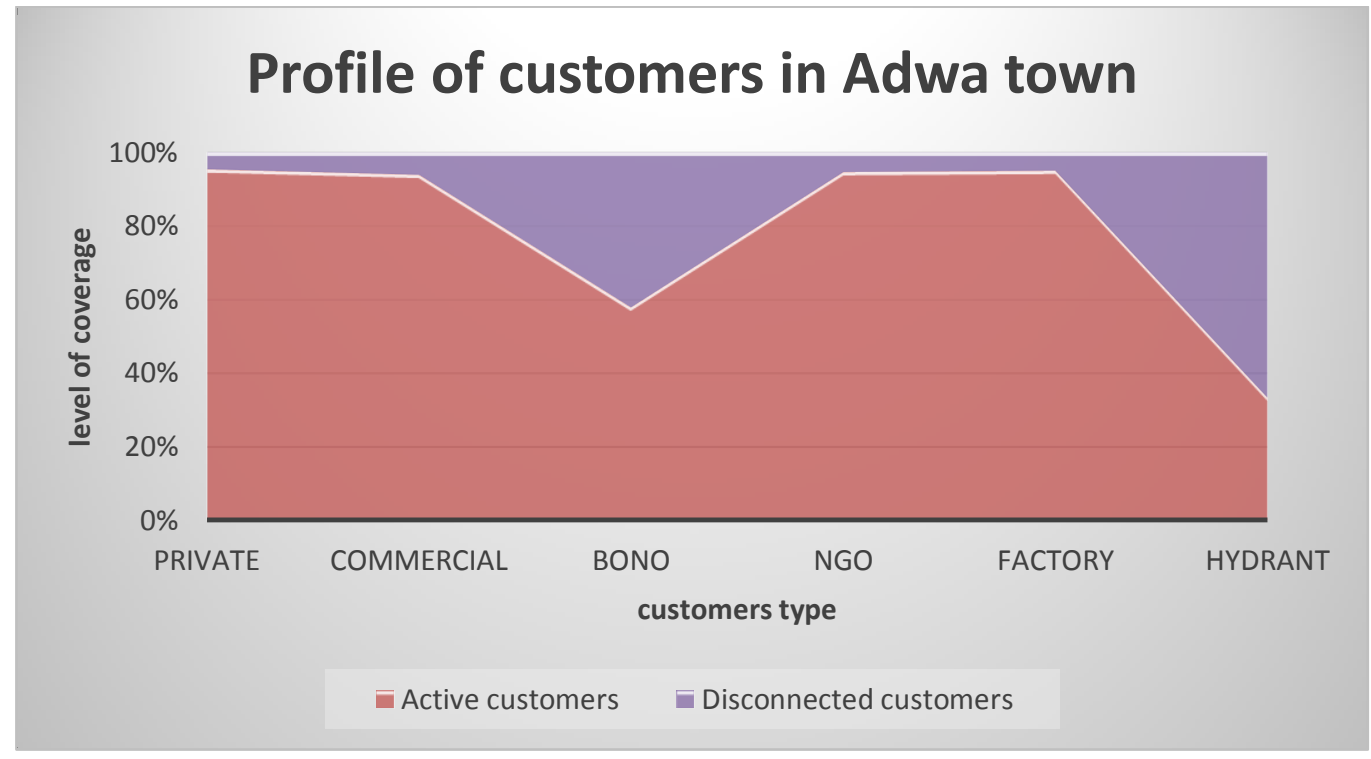

Figure 0.3:- Profiles Customers water coverage information system.

\section{Average daily, per capita consumption:}

The volume of water consumed for the domestic purpose has been aggregated to the districts of the town to Analyses the distribution of the water supply coverage among different localities. The annual consumption data has been converted to average daily per capita consumption using the number of populations. The average daily Per capita consumption of each district was derived using the following expressions:

per capita consumption $\left(\frac{\frac{l}{c}}{\text { day }}\right)=\frac{(\text { Annualconsumption }(m 3)) * \frac{10001}{\mathrm{~m} 3}}{\text { (population number of each district } * 365 \text { days }}$

Table 0.1:- Water supply coverage of Adwa town.

\begin{tabular}{|l|l|l|l|l|}
\hline Year & $\begin{array}{l}\text { consumption } \\
\left(\mathrm{m}^{3} / \text { year }\right)\end{array}$ & $\begin{array}{l}\text { populatio } \\
\mathrm{n}\end{array}$ & $\begin{array}{l}\text { consumption } \\
\mathrm{m}^{3} / \text { person/year }\end{array}$ & $\begin{array}{l}\text { consumption } \\
1 / \text { person/day }\end{array}$ \\
\hline $\begin{array}{l}\text { April } 2018 \text { to April } \\
2019\end{array}$ & 973075 & 70,742 & 13.76 & 37.69 \\
\hline
\end{tabular}


As shown from the table, the distribution of average domestic water supply coverage of Adwa town in the April 2018 to March 2019 is found to be 37.69 1/capital /day, this average per capita consumption is lower when compared to the town water demand consumption that is according to $60 \mathrm{l} /$ capita/day (MOWE, 2006).

Table 0.2:- Production of the town.

\begin{tabular}{|l|l|l|l|l|}
\hline year & production (m3/year & billed data m3 & total population & Water Production 1/person/day \\
\hline April 2018 to Mar 2019 & 1392181 & 973075 & 70742 & 53.92 \\
\hline
\end{tabular}

(Source: Adwa water supply and sewerage office, December,2018)

\section{Level of connection per family}

The total number of domestic connections (12356) within the town. The typical number of persons per housing unit 4.1 in Adwa town to compare the distribution of the water connections among the different districts, the total numbers of Connections per district are converted to connection per family using the population data of each district, it gives the following expression,

Level of connection family $=\frac{\text { total number of connection by district })}{(\text { no of population by district }) /(\text { average family size }))}$

Table 0.3:- Level of connection per family.

\begin{tabular}{|l|l|l|l|l|l|}
\hline Year & population & $\begin{array}{l}\text { Average family } \\
\text { size }\end{array}$ & $\begin{array}{l}\text { Total number of } \\
\text { connections }\end{array}$ & $\begin{array}{l}\text { level } \\
\text { connection }\end{array}$ \\
\hline $\begin{array}{l}\text { April } 2018 \text { to April } \\
2019\end{array}$ & 70742 & 4.1 & 12356 & 0.716 \\
\hline
\end{tabular}

From this table shows, the level of the connection per family for the entire town in 2018/2019 is found to be 0.716 . This event that at average the water consumption is explained by level of the population size.

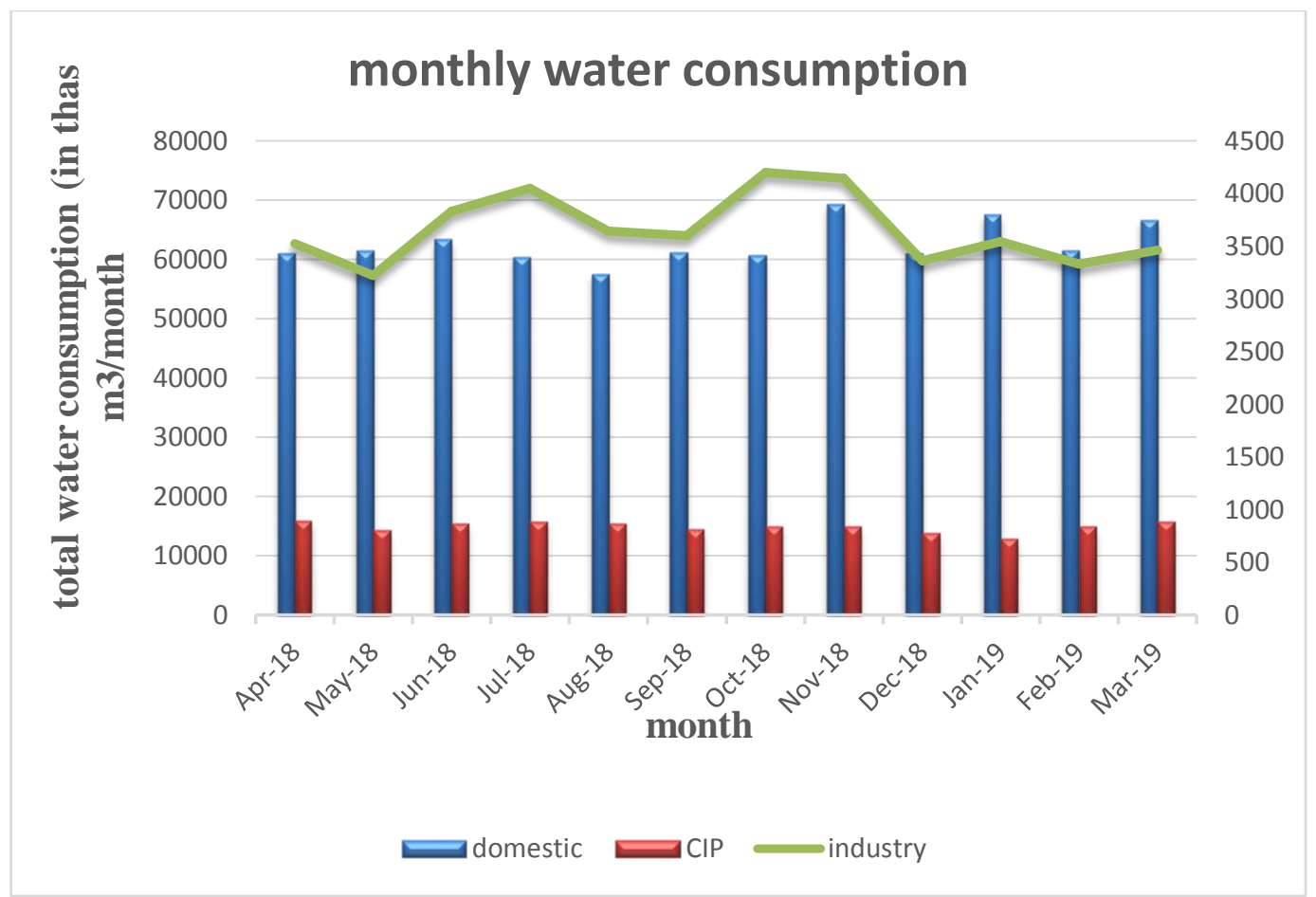

Figure 0.4:-water consumption and its composition.

As shown from the above figure in April 2018 to march 2019 the total water consumption in Adwa town was $973075 \mathrm{~m}^{3} /$ year or $77.21 \%$. in terms of composition, urban resident's commercial, institutional and public water consumption was $177886 \mathrm{~m}^{3} /$ year or $18.28 \%$ of total consumption, industrial consumption was $43889 \mathrm{~m}^{3} /$ year or $4.51 \%$ of total consumption. 




CIP = commercial, institutional and public Water consumption .

Figure 0.5:- Water consumption structure in Adwa town.

\section{Water balance system of Adwa town:}

Essentially ahead of assigning nodal water demand, it is very common to quantify water loss in water supply distribution network the number of water losses in the system from the system input meter to the customers Billed Authorized Consumption is in the quantity of water loss crossways the system is estimated by doing water balance analysis. The difference between the produced and water consumed water is quantified as total water loss. Water loss in the system is frequently due to either leakage in the system or apparent loss which includes; meter inaccuracy, illegal use of water by an authorized person. As shown in the table below 3.14 based on the analysis results the total water loss from the system is $1392181 \mathrm{~m}^{3} /$ year and is the Non -revenue water $30.10 \%$ of the system views volume.

It observed from the figure in the above table, the estimated annual volume of NRW in urban water utilities of Adwa town water balance for the year April 2018 to March 2019 is provided accordingly total water supply production to the city is $1392181 \mathrm{~m}^{3} /$ year while the corresponding consumption is $973075 \mathrm{~m}^{3} /$ year the resulting water loss 419,106 $\mathrm{m}^{3} /$ year.

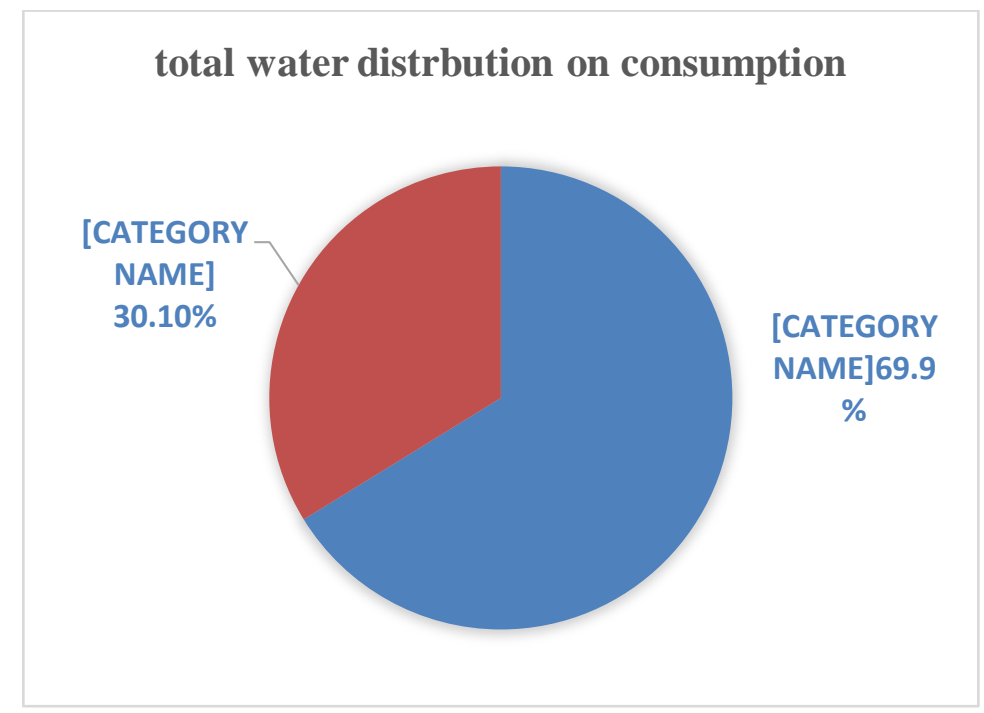

Figure 0.6:- Monthly water loss distribution curve based on the cumulative value. 
The total non -revenue water during the analysis 2019 was recorded as $419106 \mathrm{~m}^{3}$ /year. those amounts of water loss was grouped under Apparent loss / Real loss. (UARL) or lowest attainable was implemented as the total physical loss in the system, and it was analyzed as, According to some literature, a comparison of water loss between different areas is recommended to be done using the water loss per service connections per day. Taking the total number of connections in the town as 12,356 the water loss per connection for a similar duration was derived as,

Water loss $=419,106 \frac{\mathrm{m} 3 / \text { year } \times 1000 \mathrm{l} / \mathrm{m} 3}{(12,356 \times 365 \text { days })}=92.93 \frac{\frac{\text { liter }}{\text { connection }}}{\text { day }}$

According to Sharma (2008), performance indicator physical losses target matrix: Adwa town is water loss per number of connections were found in good condition system which is less than $<250$ Liter/connection /day. This figure shows as litters per service connection per day increases water losses also increase. The UARL is based on the result of an international survey containing data from 20 country's (lambert, 2002). based on the equation above the infrastructure leakage index (ILI) for Adwa town water supply distribution system is calculated 2.56, this shows that the current annual real loss is assessed as being around four times as high as the unavoidable annual real losses. The total length of pipes of greater or equal to $50 \mathrm{~mm}$ diameter has been used to evaluate total water loss of the entire town is $63 \mathrm{~km}$. Using total pipe length of the entire town, the water loss per kilometer length of

$($ main pipes was derived to be $)=\frac{(419106 \mathrm{~m} 3 / \text { year } \times 1000 \mathrm{~L} / \mathrm{m} 3}{(63 \mathrm{~km} \times 365 \text { days })}=18.23 \mathrm{~m} 3 / \mathrm{km} / \mathrm{day}----(0-4)$

This figure shows that as the length of the pipe increases the number of water losses per day increases.

\section{Junctions with negative pressure}

The selected junction in the figure flow is low pressure in the distribution system due to the topographic variation of the town. the area of kebele alula near to St. church and mosques is marked by very low pressure $<15 \mathrm{~m}$. This minimum pressure should be maintained in the system to avoid the water column separation and to ensure that the consumer's demand is provided at all times.

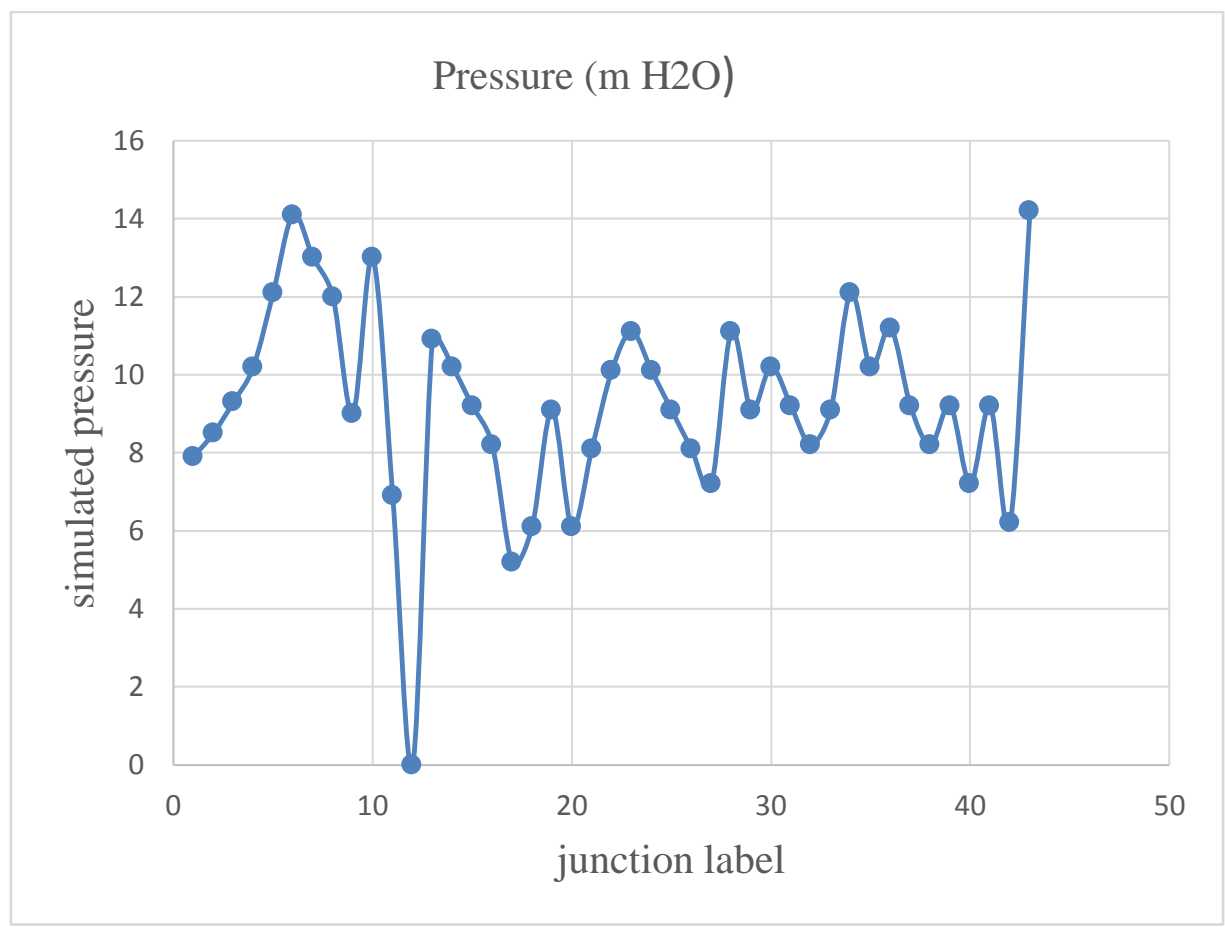

Figure 0.7:- Time series plot for selected junctions with negative pressure. 


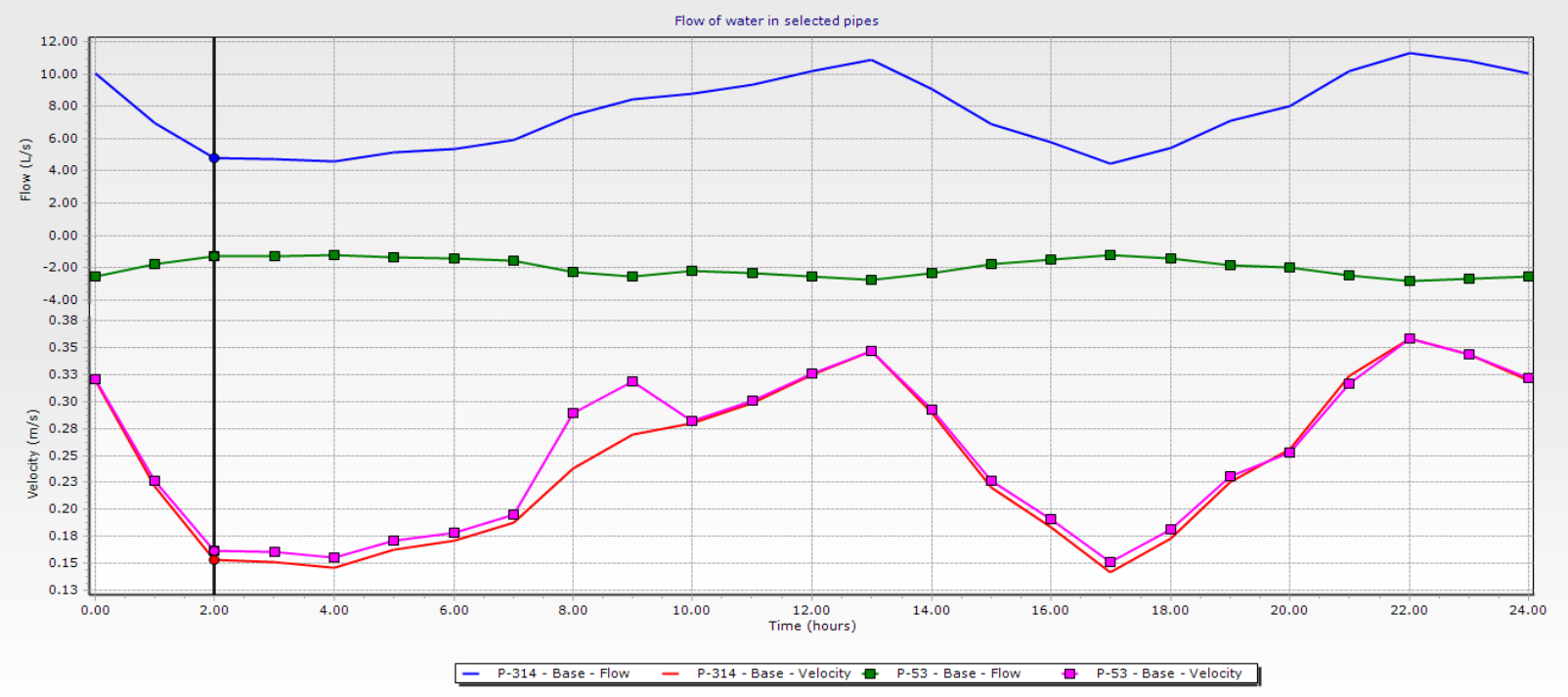

Figure 0.8:- Flow of water in the selected pipes.

\section{Pressure and Demand:}

High pressure during low demand conditions can cause pipe overflowing. leakage and large amount of water loss through the distribution network as shown in the figure below the pressure were low during day time with the increasing of the water demand of the customers and high during night hours when the demand is low. This is the graph between pressure and demand which shows the variation of pressure in different junctions is caused the changing the demand of recurrent starts and stops of the pump closing and opening of the control valve that induces water hammer. in the figure below the peak of the demand correspond with valley of pressure curve in the figure on the selected node $\mathrm{J}-213$.

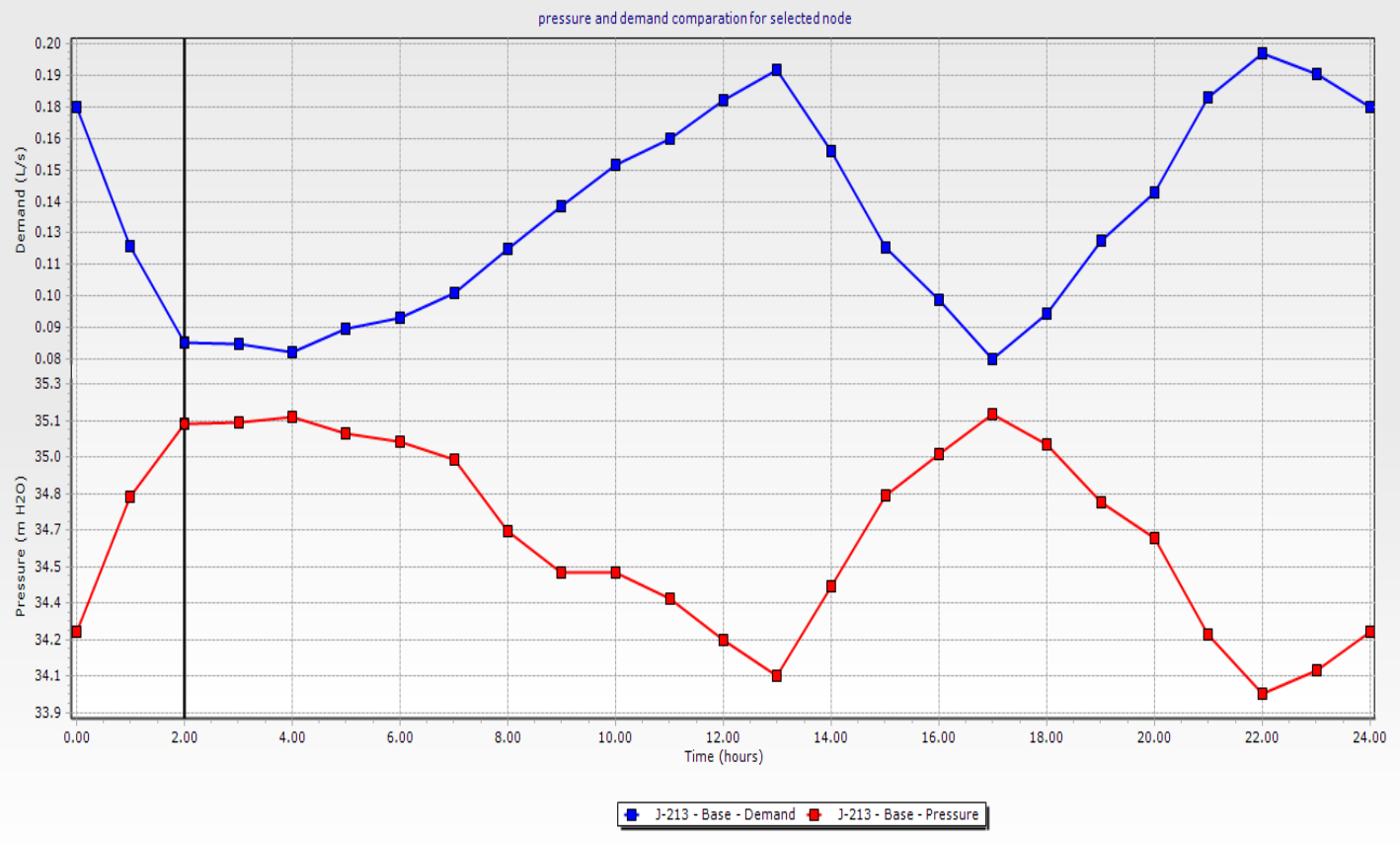

Figure 0.9:- Pressure and demand relationship. 


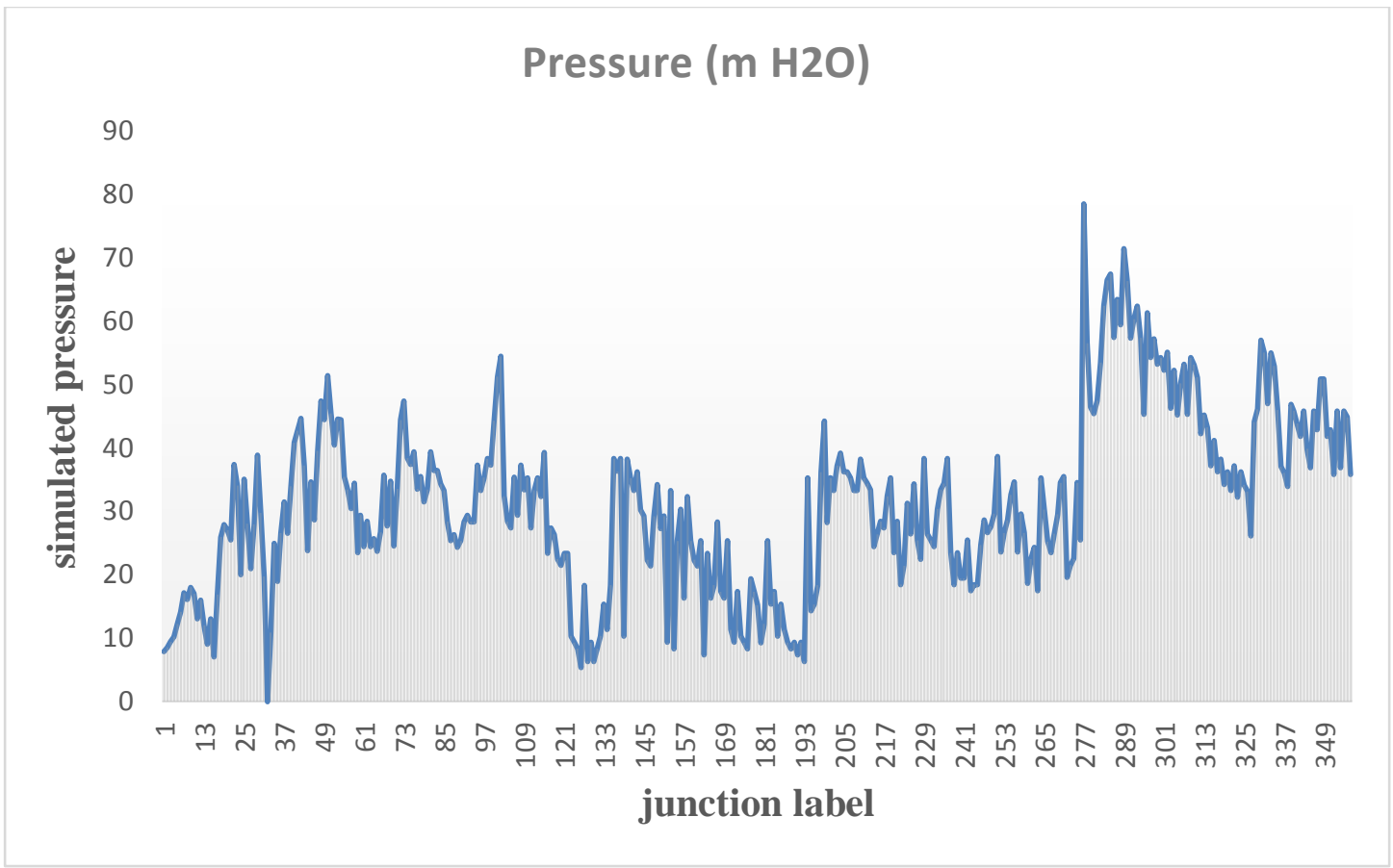

Figure 0.10:- Distribution of pressure at peak hour consumption.

\section{Velocity:}

The velocity of water flow in a pipe is also one of the important parameters in hydraulic modeling performance evaluation of the efficiency of water supply distribution and transmission line. The velocity ranges can also be adopted as the design criteria, low velocities for hygienic, while too high-velocity cause exceptional head loss reason are not preferred velocity distribution is also varying with demand pattern changes. at the peak time demand, the values are different as compare to minimum consumption hour. The water distribution network velocity during peak hour demand is summarized in figure below.

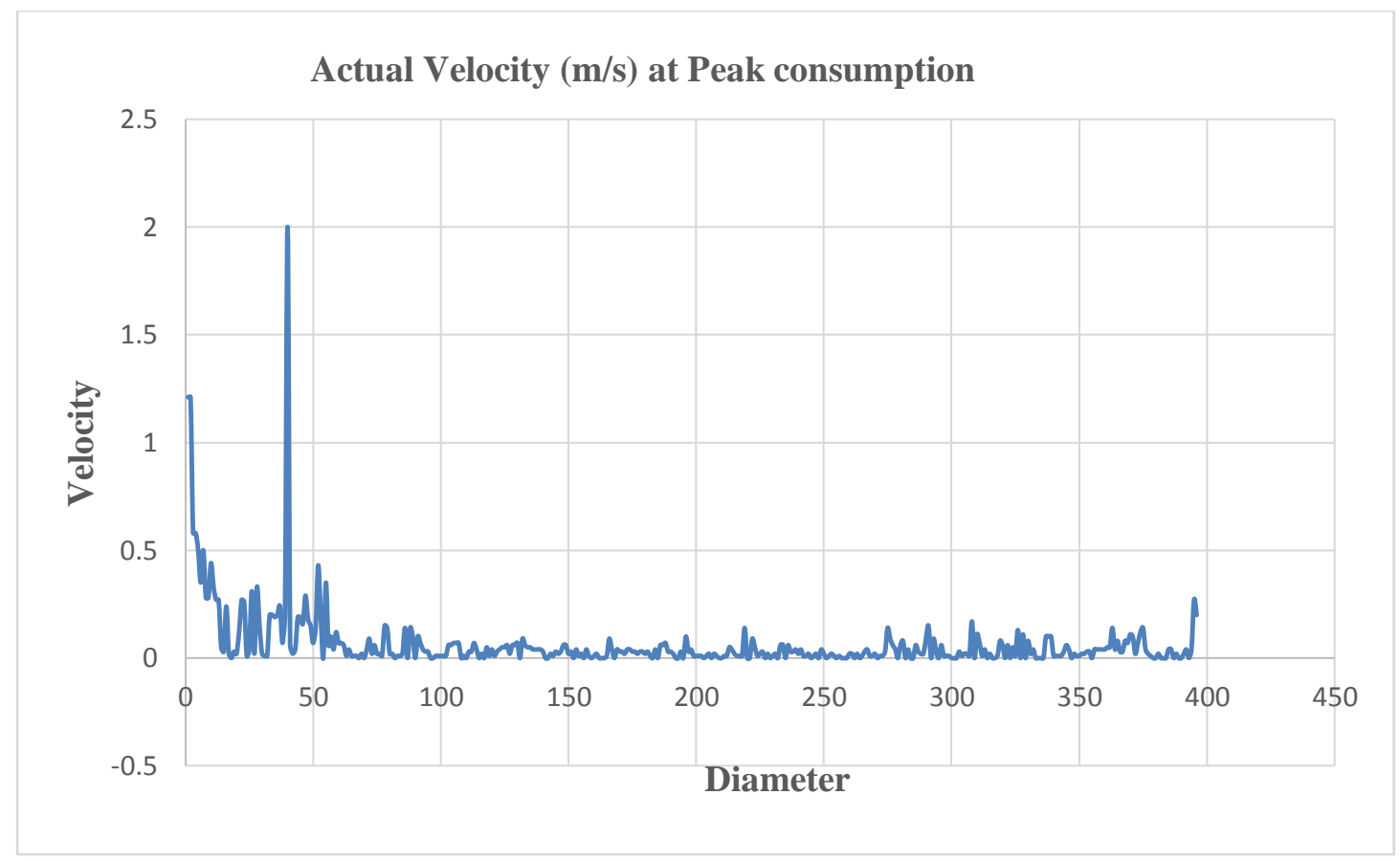

Figure 0.11:- Velocity distribution at peak hour consumption. 


\section{Hydraulic model calibration result based on difference error:}

In this research, the pressure data measured at the near to node home faucet of the system is used to assess the model performance. The model performance measure Such as the degree of accuracy (error of difference) and the coefficient of determination $\left(\mathrm{R}^{2}\right)$ are two techniques to be considered for the calibration model check as mentioned below the results. All observed pressures were equal to the simulated pressures, giving a link coefficient of one that is the best correlation between observed and simulated. The coefficient of determination $\left(\mathrm{R}^{2}\right)$ value was 0.9791 , it indicates that observed and simulated relation is strong as values tend to one. The observed and simulated pressure relationship plot is shown in the figure below.

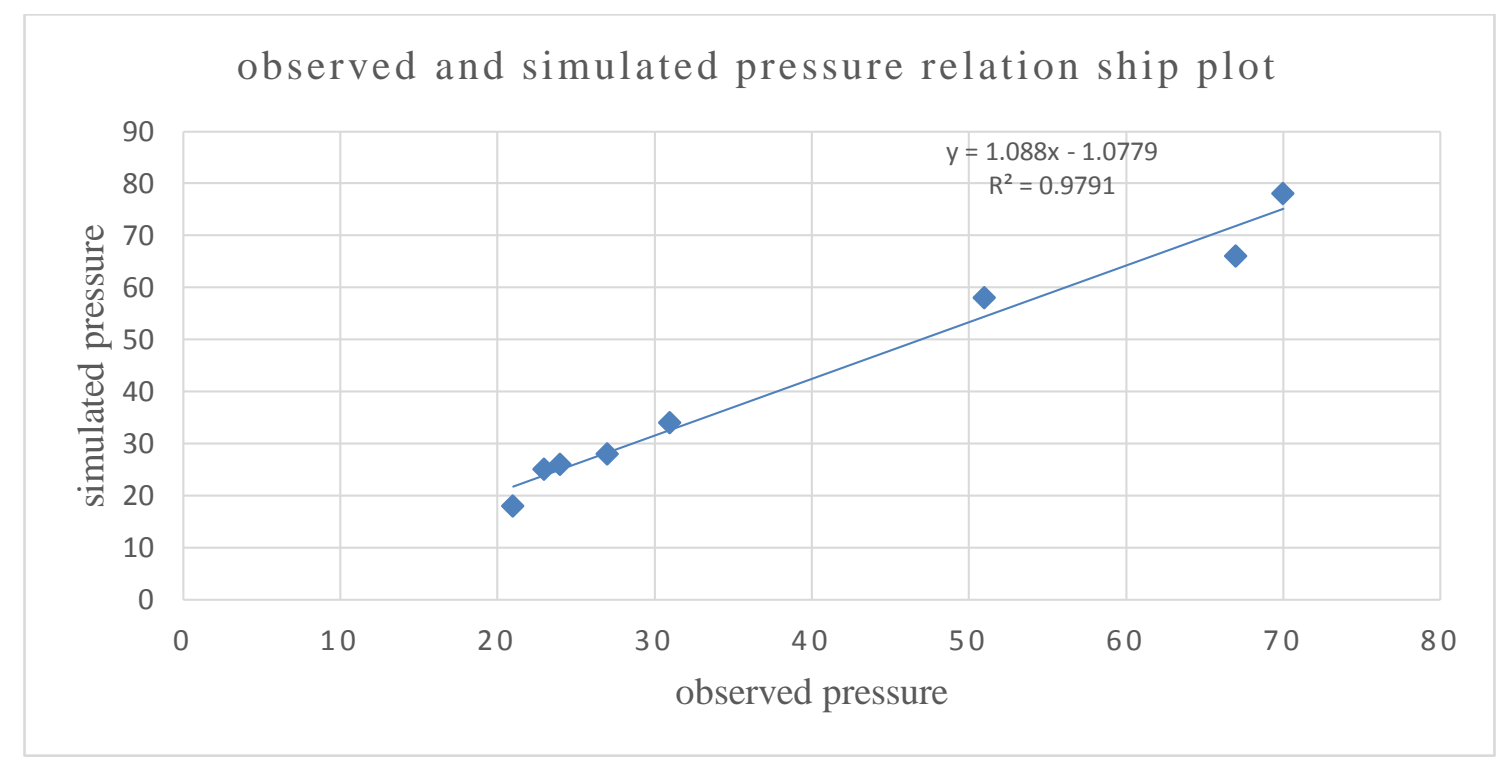

Figure 0.12:- Correlation between observed and simulated pressure relationship plot.

\section{Conclusions:-}

In this research, the water distribution, the system has been modeled with the help of water GEMS in which the number of nodes, elevation, number of pipes and demands of the Adwa town area.

Water GEMS model calibration was acceptance to capture the pressures within the WDS and exceptionally great execution of pressure nodes.

The modeling WDS is controlled the water pressure and velocity within the systems of Adwa town design standards. The infrastructure leakage index value (2.56) for this system appears that the current yearly real losses as assessed as being around three times as high as the unavoidable yearly real losses for the system. this esteem may not see exceptionally terrible in an international setting. Be that as it may, it cannot be acceptable in Adwa town water supply distribution system.

the nodal pressure in all distribution system especially at the point of lower and higher elevation area of the distribution system

The study comes about confirmed the Water GEMS modeling procedure than the conventional trial and error simulation approach by EPANET and water CAD V8i.

long last conclude that Water GEMS is capable elective for ideal design of WDS within the case study measured in terms of hydraulic results.

\section{Acknowledgments:-}

I would like to express almighty God who has allowed me the opportunity to start, and the potential to complete my study. He stood on my side and enabled me to reach this far and more so achieved my aspiration in life. 
I would like to express my profound appreciation to my advisor Dr. Sisay Demeku for his continuous and eager guidance and encouragement as well as his invaluable advice and patient throughout this research work particularly.

My gratitude also goes to Dr. Adanech Yared for her respected and helpful comments during proposal development. lastly, my heartfelt thanks and appreciation goes to my wife Instructor genet Tadege and our children Petros Tsegay without their moral support and love, it could have been more difficult to complete my study.

\section{Reference:-}

1. A.O. Lambert, and D. R. D. M. (2002). Practical Experience in using the Infrastructure Leakage Index. (November).

2. Abdelmeguid, H., \& Ulanicki, B. (2012). Pressure and Leakage Management in Water. 1124-1139.

3. Abraham, Belay and Ali, M. (2018). State of Water Supply and Consumption in Urban Areas at Household Level: A Case Study of East Wollega Zone, Ethiopia. (May 2012).

4. Adachi, S., Takahashi, S., \& Zhang, X. (2015). Estimation of area leakage in water distribution networks : a real case study. Procedia Engineering, 119, 4-12. https://doi.org/10.1016/j.proeng.2015.08.846

5. Asgedom, D. B. (2014). Assessing Causes and Challenges of Urban Water Supply: The Case of Mekelle City. 3(7), 1922-1928.

6. AWWA. (2017). Computer Modeling of Water Distribution Systems.

7. BEHUTE, M. (2016). Assesment of welkite water supply system in gurage zone, snnpr, Ethiopia.

8. Bhoyar, R. D., \& Mane, S. J. (2017). International Journal of Advance Engineering and Research Modelling and optimization of water distribution system site : nagpur. 210-221.

9. Brown, K. (2007). Florida State University Libraries Modeling Leakage in Water Distribution Systems.

10. Bwire, C., Onchiri, R., \& Mburu, N. (2015). Simulation of Pressure Variations Within Kimilili Water Supply System Using Epanet. International Journal of Civil Engineering and Technology, 6(4), 976-6308.

11. Ciobanu, Natalia, J. K. \&. (2013). Dynamic modelling of water demand and supply in istanbul, turkey.

12. EPA. (2010). Control and mitigation of drinking water losses in distribution systems.

13. Calibration by WaterCAD at El-Nozha Water Network in. (July), 845-861.

14. Ismael, Addis, Selamawit. A Senait T. , Zinash. D, G. . . (2014). Tigray water resource bureau study and detail design of additional treatmenet plant for midimar dam project Detail Design Report ( Revised Final ).

15. Lambert, Allan, Vermersch, M., Carteado, F., Rizzo, A., Johnson, E., \& Arregui, F. (2016). Guidance notes on apparent losses and water loss reduction planning.

16. Maruf, M., Abrar, M., \& Chowdhury, A. (2016). Water Distribution System Modeling By Using MOWE. (2006a). Urban Water Supply Design Criteria.

17. Zewdu, A. (2014). Assessing Water Supply Coverage and Water Losses from Distribution System for Planning Water Loss Reduction Strategies ( Case Study on Axum town. 